\title{
Assessment of Peat Deposits in Rwanda
}

\author{
Theophile Mugerwa1,2, Olugbenga A. Ehinola¹, Ibrahim A. Oladosu', Digne Rwabuhungu² \\ ${ }^{1}$ Institute of Life and Earth Sciences (Including Health \& Agriculture), Pan African University-University of Ibadan, Ibadan, \\ Nigeria \\ ${ }^{2}$ School of Mining and Geology, University of Rwanda, Kigali, Rwanda \\ Email: luanmugerwa@gmail.com
}

How to cite this paper: Mugerwa, T., Ehinola, O. A., Oladosu, I. A., \& Rwabuhungu, D. (2020). Assessment of Peat Deposits in Rwanda. Journal of Geoscience and Environment Protection, 8, 1-11. https://doi.org/10.4236/gep.2020.810001

Received: August 21, 2020

Accepted: October 11, 2020

Published: October 14, 2020

Copyright $\odot 2020$ by author(s) and Scientific Research Publishing Inc. This work is licensed under the Creative Commons Attribution International License (CC BY 4.0).

http://creativecommons.org/licenses/by/4.0/

\begin{abstract}
The peat deposits in Rwanda are distributed over an area of 50,000 ha and were formed about the end of last glaciations period. However Akanyaru peat is 20,000 years old and contains peat of glacial and postglacial period. The studies show that Rwanda has 155 million tons of dry peat which can generate electrical energy and this deposit is sufficient to meet country's vast energy requirements for 30 years. Hence, it was felt necessary to map prospective locations of peat and their energy potential. The result of the study and assessment of peat to power in Rwanda show that the average in-situ ash content, in-situ moisture content and in-situ bulk density of the collected peat samples are $36 \mathrm{wt} \%, 70.8 \mathrm{wt} \%$ and $1112 \mathrm{~kg} / \mathrm{m}^{3}$ respectively. Their average thickness ranges from 0.9 to $7.8 \mathrm{~m}$. In Finland, peat was used as fuel in 1996 and produced $10 \%$ of total installed capacity. Rwanda has the same operational peat power plant in Gishoma: Rusizi District generating $15 \mathrm{MW}$ connected to the national electrical grid. A peat-fuelled power plant is under construction and is expected to generate $80 \mathrm{MW}$. This plant, once completed, is expected to connect $50 \%$ more households into national grid. Thus, this effort along with other projects will increase electrical power from $208 \mathrm{MW}$ to $563 \mathrm{MW}$ in 2024. Peat deposit is expected to generate 500 Megawatt electrical powers for 30 years. Although an effort was done to use peat as fuel, the power plant is still vulnerable to the lack of good quality of dry peat to operate and thus efforts are on to develop suitable technology for exploitation.
\end{abstract}

\section{Keywords}

Peat Deposits, Electrical Power, Energy, Rwanda

\section{Introduction}

Peat has been used as energy about 2000 years as substitute for firewood and heating. The use of gas and oil during the $20^{\text {th }}$ has shadowed the use of peat 
(Andriesse, 1988) but the high demand for electricity has stimulated the construction of peat fired power plant. It was used as fuel in four countries namely former Soviet Union, Sweden, Ireland and Finland in the world in 1996 (Schora \& Punwani, 1980). In Ireland for example, peat has been used for electricity generation since 1950 , and it is estimated at $10 \%$ of the total installed capacity (Sarkki et al., 2012). Rwanda has approximately 155 million tones of dry peat over an area of 50,000 ha of peat (Ekono, 1992), most of which is located in South and South west of the Country. These deposits were formed about the end of the last glaciations period and this implies that they are less than 10,000 years old (Andriesse, 1988; Pajunen, 1996).

However, peat deposit in Akanyaru is 20,000 years old and thus it contains peat of glacial and postglacial period (Pajunen, 1996). These deposits were formed as a result of the formation of East Africa lift Valley which caused the Precambrian rocks of Lake Tanganyika to sink in $700 \mathrm{~m}$ below sea level and the Ruwenzori area to elevate to more than $5000 \mathrm{~m}$ above sea level and therefore it has changed the East Africa plateau. This period has triggered the formation of new lakes and flow direction of rivers. The topographical and hydrological architect of tropical swamps in Rwanda is basically influenced by recent volcanism. Because the lava flow blocked the valley, the age of these peat deposits are more likely to be influenced by volcanic activity than climate change (Andriesse, 1988). Rwanda has the operational peat power plant in Gishoma; Rusizi District generating $15 \mathrm{MW}$ connected to the national electrical grid. Rwanda Cement Company uses 13,000 tons per year of wet peat; however it is still vulnerable to its limited capacity to sustain large scale peat production that could handle up to 50 MW of power (Namata, 2014). Hence, it was felt necessary to map all prospective locations of peat and their energy potential for future exploitation.

Under the aegis of the Energy division, Rwanda Ministry of Infrastructures, a comprehensive research-oriented peat program has been launched, emphasizing on quality, quantity and technology development with the following objectives:

1) Understanding the nature and distribution of peat in Rwanda

2) Identifying promising sites on regional scale and estimating the resource potential

3) Quantifying peat resources in Rwanda

4) Recommending suitable sites for peat exploitation

In recent times, interest has been given to peat deposits as probable models for certain coal deposits. Their distribution, low ash content, low sulfur and thickness have attracted coal geologists to study these peat bogs along with some brown coal deposits (Dehmer, 1993; Staub et al., 1991). Scientific research is the only way to justify if the recent peat deposit can be provided as models for certain coal basin.

\section{Geological Settings}

Rwanda falls into Kibaran belt (KIB) of the Central Africa which is a belt of Me- 
zoproterozoic supracrustal units composed of metasedimentary rocks and minor metavolcanic rocks. S-types granitoid and mafic rocks (Fernandez-Alonso et al., 2012; de Clercq et al., 2008) have intruded it. The NE Kibaran Belt as it is known as Karagwe-Ankole Belt (KAB) consists of two different structural domains namely WD (Western Domain) and ED (Eastern Domain) (Figure 1) and each domain has a specific sedimentary sub-basins and depositional conditions (Fernandez-Alonso et al., 2012). The WD is referred as Akanyaru Supergroup while the ED is Kagera Supergroup. WD is composed of Rwanda, part of Katanga in DRC up to Ankole region of SW Uganda. This super group is underlain by Palaeoproterozoic basement. The older granites and gneisses dominate the eastern province while the northwestern is made up of neogene volcanics.

The young alluvium and lakes sediments dominate the southwestern part of the country (Figure 2). The sedimentary sequences indicate the influence of shallow marine and high energy environment due to stratification, conglomerates and symmetric ripple marks found within the layers. The western rift of western part of Rwanda is filled with tertiary and quaternary clastic sediments (Thomas, 2006).

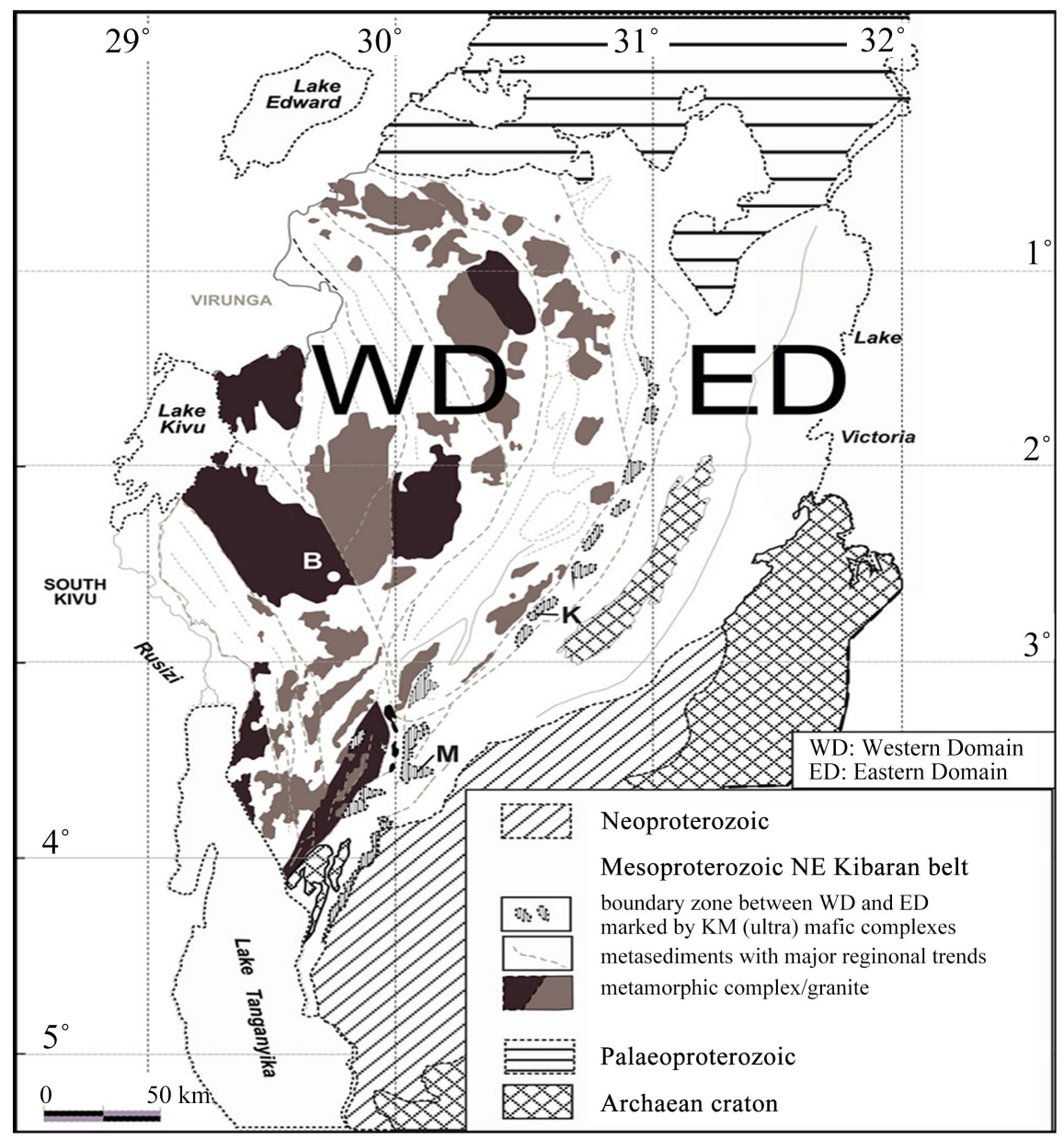

Figure 1. Regional framework of the Karagwe-Ankole belt (Fernandez-Alonso et al., 2012). 


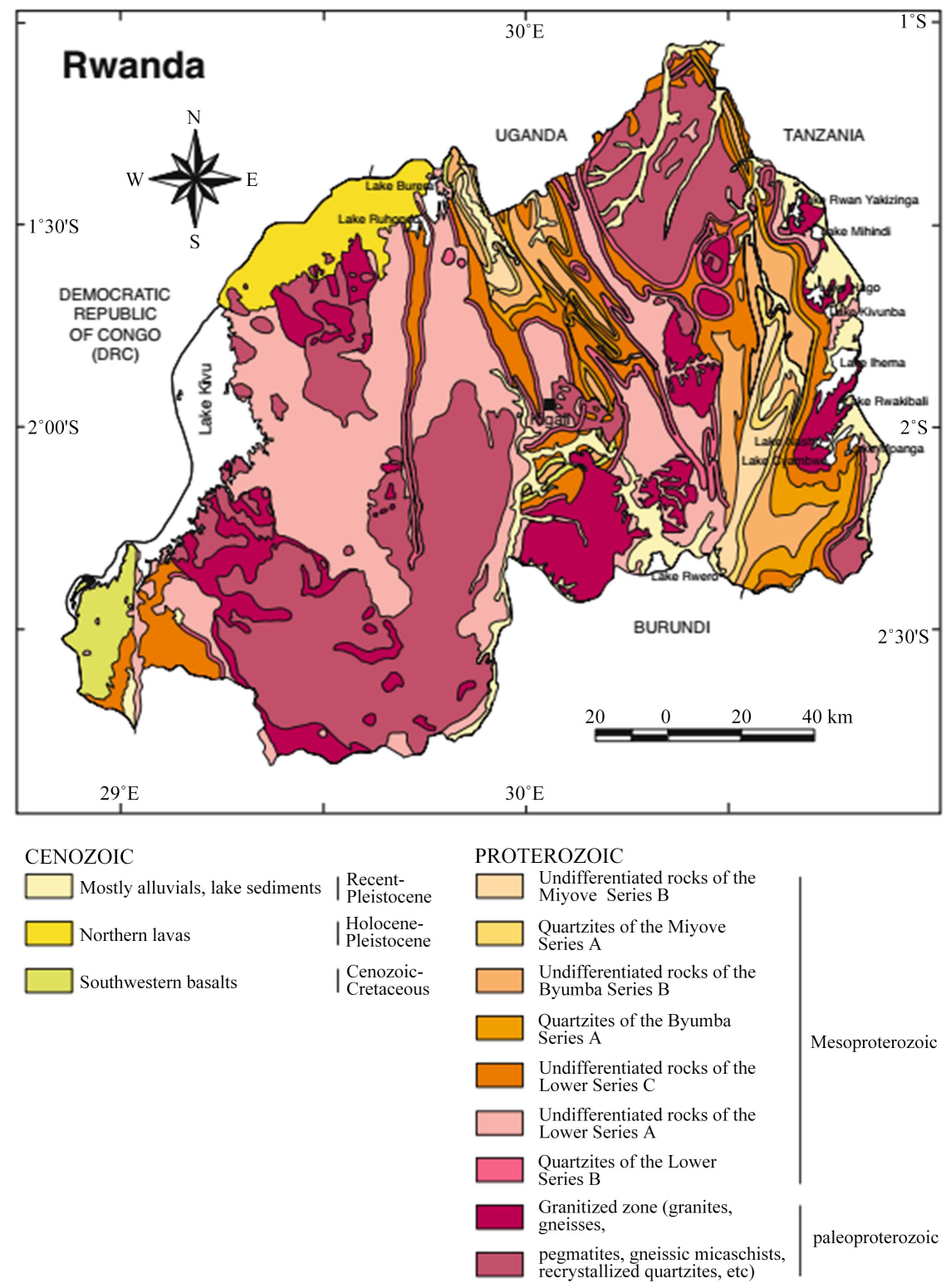

Figure 2. Geological overview of Rwanda (Thomas, 2006).

\section{Proximate Analysis Parameter and Calorific Value of Low Rank Coal}

Peat is low rank coal, which is made of plant remains as evidenced by the presence of biomarkers detected through chemical, geological, and petrographic studies (Del Rio et al., 1992). It is sedimentary deposit formed principally from plants and rarely from inorganic substances. It is, thus, an aggregate of macerals or premacerals and minerals that when subjected to certain processes, can be converted to coal (Mugerwa et al., 2019). Coal is used for power generation, steel making, cement production, and many other purposes around the world. The billions of tons of coal are merchandised every year in local and international market. The quality of coal, the desirable purpose of use and the quantity deter- 
mine its price.

The properties of coal, which have on burning and environmental performance regularly, form the basis of sale agreements, and they include calorific value, volatile matter, moisture content, sulfur, and ash content of the coal (Zhu, 2014). The main purpose of coal sample analysis is to determine quality or rank of coal. The simplest and most common form of coal evaluation is to determine moisture content, volatile matter, and ash and by difference fixed carbon with the coal sample.

\subsection{Moisture Content}

Coals are mined from the ground with some moisture allied with them. Slightly heating the coal samples above boiling points water $\left(100^{\circ} \mathrm{C}\right)$, the loss of the weight is defined as moisture content. Normally coal accounts $5 \%$ to $70 \%$ moisture content. High moisture content is not desirable because it reduces the heating value of coal. There are four forms of moisture within coal samples, which are:

1) Surface or free moisture (water held by the surface of the coal particles or macerals),

2) Residual moisture (water held by capillary action with a pore),

3) Decomposition moisture (water produced from the thermal decomposition of organic constituents of coal) and,

4) Mineral moisture (water, which comprises parts of crystal structure of hydrous silicates such as clay or inorganic minerals in coals) (Zhu, 2014).

Proximate analysis of moisture determines the total and/ or residual moisture content of coal. The total moisture content of coal consists of surface and inherent moisture content and it is measured on as received basis while residual moisture content is moisture measure on air-dried samples (Zhu, 2014; Ahmed et al., 2019). In this study, the reported moisture is residual because before measuring the moisture content the samples were air-dried.

\subsection{Ash Content}

Ash is the residue remaining after the combustion of coal in air and is derived from inorganic compounds existing in original coal substance and from accompanying mineral matter (Zhu, 2014). The results of analysis show the ash yield that is indicator of the grade and quality of coal since it offers amount of incombustible materials. The high ash yield, lower the calorific value of coal (Ahmed et al., 2019). According to Zhu (2014), the residue remaining after heating $1 \mathrm{~g}$ of coal/peat, if weighted will be equal to ash yield.

\subsection{Volatile Matter}

Volatile matter in a peat refers to the thermal decomposition products liberated when a peat is heated at high temperature in the absence of air. The volatile matter obtained during analysis of coal is mainly composed of combustible gases 
such as hydrogen, carbon monoxide, hydrocarbon, tar, ammonia and incombustible gases carbon dioxide and steam (Zhu, 2014; Ahmed et al., 2019). The VM is used to rank the coal and to establish coal-burning characteristics.

\subsection{Fixed Carbon}

Fixed carbon in a coal is the carbon that remains in a coal sample after volatile matter is driven off. The ratio of fixed carbon to proximate VM, the fuel ratio, is used as measure of combustion reactivity and burnout (Ahmed et al., 2019). The fixed carbon is not determined directly, it is rather calculated by subtracting from 100 the sum of moisture, VM and Ash yield (Zhu, 2014).

\subsection{Calorific Value}

Calorific value is a direct indication of heat content (energy value) of the coal. It is crucial parameter for coal mining and combustion and it used standard of coal quality and hence its economic value. The calorific value is the property, which defines the valuation of biomass as a fuel (Sheng \& Azevedo, 2005; Ahmed et al., 2019). Therefore, once measured, it determines significantly if it can be mined as an economical and environmental energy source. Calorific Value may be measured or calculated from ultimate/proximate analysis (Ahmed et al., 2019). In this study, the calorific value was measured not calculated. The CV is defined as the amount of heat evolved when a unit weight of biomass is burnt completely and the combustion products cooled to a standard temperature of $298 \mathrm{~K}$ (Shirazi et al., 1995; Ahmed et al., 2019).

\section{Quantitative and Qualitative of Peat Deposits in Rwanda}

The coal is the product of fossilization of plant remains as evidenced by the detection of biomarkers based on chemical, geological and petrographic studies of coal (Del Rio et al., 1992). Peat is sedimentary deposit formed principally from plants and rarely from inorganic substances. It is, thus, an aggregate of macerals or pre-macerals and minerals that when subjected to certain processes, can be converted to coal. According to Cohen et al. (1987), it is difficult to place a precise boundary between what might be a precursor of carbonaceous shale and what might be a precursor of a coal. However, it is agreed that the precursor of a good coal should consist of at least 70\% dry weight of organic material (Del Rio et al., 1992).

Peat is organic sediments from plants and seldom from inorganic substances deposited in situ or transported. It is subjected to different processes such as coalification to become coal (Del Rio et al., 1992). The usage of coal /peat is related to its geochemical properties. For example, coal/peat with high sulfur and high ash content is not suitable for energy production. The high sulfur content is environmentally harmful whereas the high ash yield reduces the heating value of the peat. The economic potential of fossil fuel is evaluated based on its chemical and fuel properties (Table 1). 
Table 1. General chemical and fuel properties of a range of fossil fuels (modified by Theophile Mugerwa, after Lindström, 1980).

\begin{tabular}{|c|c|c|c|c|c|}
\hline & & Coal & Lignite & Peat & Wood \\
\hline \multicolumn{6}{|c|}{ Chemical composition } \\
\hline Carbon (C) & weight $\%$ & $76-87$ & $65-75$ & $50-60$ & $48-55$ \\
\hline Hydrogen $(\mathrm{H})$ & weight $\%$ & $3.5-5.0$ & $4.5-5.5$ & $5-7$ & $6-7$ \\
\hline Oxygen $(\mathrm{O})$ & weight $\%$ & $3-11$ & $20-30$ & $30-40$ & $38-43$ \\
\hline Nitrogen $(\mathrm{N})$ & weight $\%$ & $0.8-1.2$ & $1-2$ & $0.5-2.5$ & $<0.6$ \\
\hline Sulphur (S) & weight $\%$ & $1-3$ & $1-3$ & $0.1-0.4$ & $0.02-0.06$ \\
\hline \multicolumn{6}{|c|}{ Fuel properties } \\
\hline Volatile matter & weight $\%$ & $10-50$ & $50-60$ & $60-70$ & $75-85$ \\
\hline Ash & weight $\%$ & $4-10$ & $6-10$ & $2-15$ & $0.1-2.0$ \\
\hline Bulk density & $\mathrm{kg} / \mathrm{m}^{3}$ & $728-880$ & $650-780$ & $300-400$ & $320-420$ \\
\hline Effective calorific value of dry substance & $\mathrm{MJ} / \mathrm{kg}^{1}$ & $28-33$ & $20-24$ & $20-23$ & $17-20$ \\
\hline $1 \mathrm{MJ} / \mathrm{kg}=239 \mathrm{Kcal} / \mathrm{kg}$ & & & & & \\
\hline
\end{tabular}

The researchers have appraised 155 million tones of peat on dry basis across the country (Hakizimana et al., 2016; Ekono, 1992) and these deposits could be converted into energy (Vitikka \& Lahtinen, 2013). Table 2 shows estimated quantity from selected peat deposits. Figure 3 represents the surveyed peat deposited in Rwanda. The potential peat resources vary from one location to another.

The procedures outlined by the American Society for Testing and Materials (BIS, 2003; ASTM-E711, 1987) were followed to determine total moisture, volatile matter, ash, fixed carbon, total sulfur and calorific and some of the results are presented in Table 3. The high moisture content (average 70.88\%) is typical of peats $(70 \%-90 \%)$. The total Sulfur \% values (average $0.84 \%$ ) are generally medium for all samples. The gross calorific values of peat samples ranged from 3107 to $5258 \mathrm{Kcal} / \mathrm{kg}$, with an average value of $4302 \mathrm{Kcal} / \mathrm{kg}$. These values are moderately very high because typical dry peat has calorific values of 2000 $\mathrm{Kcal} / \mathrm{kg}$ (Hoş-Çebi \& Korkmaz, 2015).

The average ash content of samples taken from different location is displayed in Table 3 where Mashya display the lowest value (20\%) while the highest ash content $(80 \%)$ is found in Kageyo. The average ash content in all studied location is $36 \%$. The moisture content in all locations is slightly high ranging from $53 \%$ to $85 \%$. Kaguhu and Kageyo display the lowest moisture content (53\%) while Akanyaru North (other, South) is featured with highest value (85\%). The ash content of less than $40 \%$ in soda peat dried up to $30 \%$ moisture content and less than $30 \%$ in milled peat dried to $40 \%$ is suitable for electrical power generation (Mugerwa et al., 2019).

In previous research conducted by Theophile Mugerwa (2020) and presented in Figure 4, that most of the samples are in three zones namely Mashya, Gishoma and Gihitasi fall within useful zones. Some are very useful, useful; condition- 
al useful and other in useless zones and thus an attempt to further treatment of peats is required to use it. The usefulness may be associated with volatile matter, ash content and sulfur content. In this content, if sulfur is slightly high, there is a need to development air treatment exercise before using it. This supplement the previous research (Mugerwa et al., 2019; Hakizimana et al., 2016; EDCL, 2014) stated that Gishoma and Mashya are good deposits for peat to power.

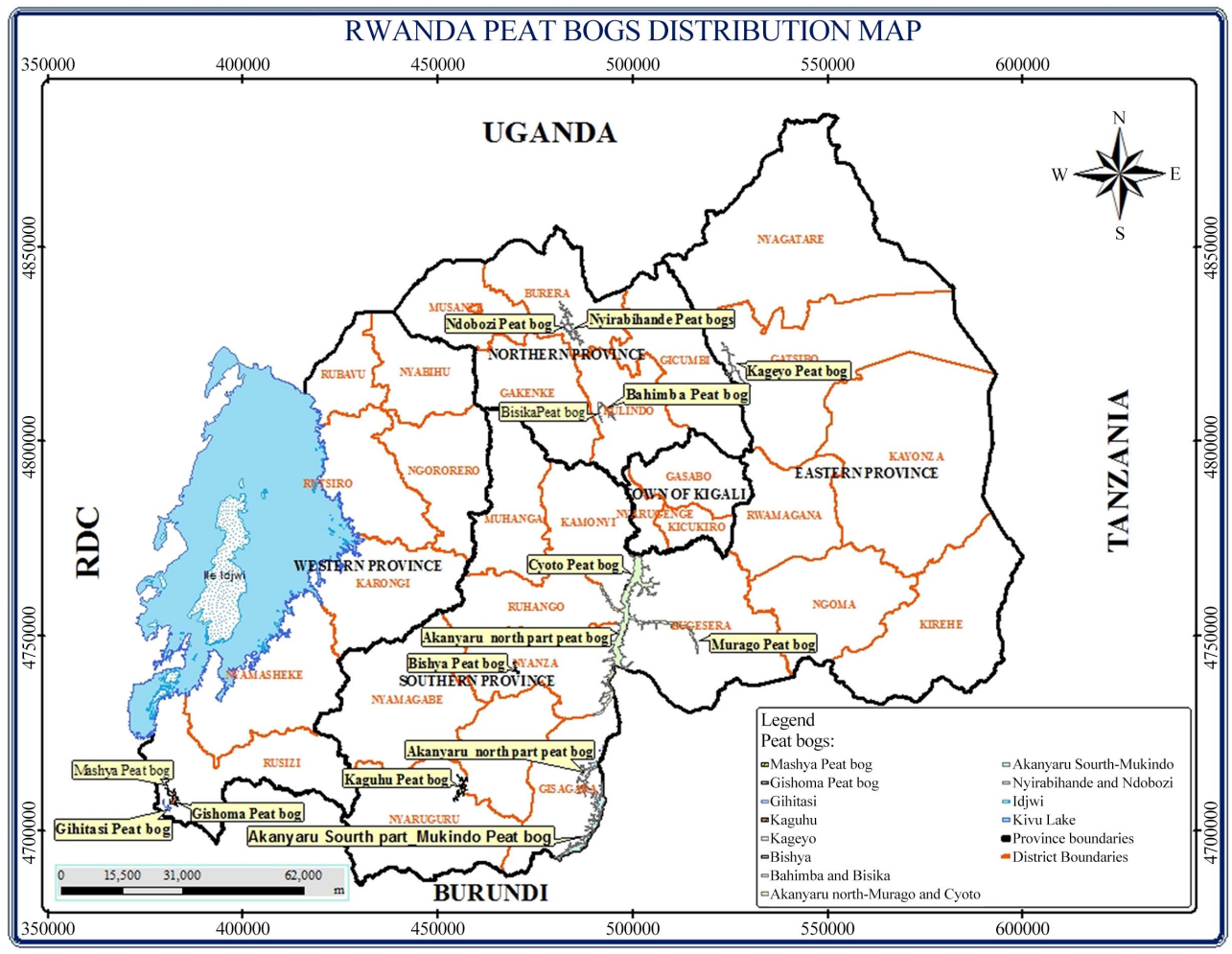

Figure 3. Peat distribution map_Rwanda.

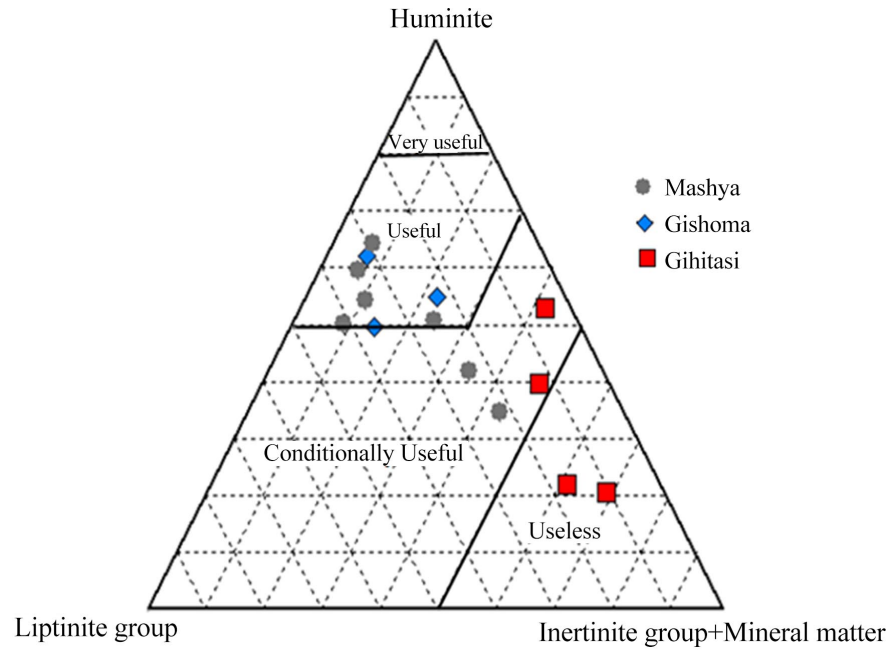

Figure 4. Classification of usefulness of peats from Mashya, Gihitasi and Gishoma for clean coal technology based on petrographic composition (modified by authors after Bielowicz, 2013). 
Table 2. Peat reserves in Rwanda (sampled locations) (EDCL, 2014).

\begin{tabular}{|c|c|c|c|}
\hline \multirow[t]{2}{*}{ Name of peat bog } & \multirow{2}{*}{$\begin{array}{c}\text { Area } \\
\text { (ha) }\end{array}$} & \multicolumn{2}{|c|}{$\begin{array}{c}\text { Quantity of exploitable } \\
\text { peat reserves, dry basis (tons) }\end{array}$} \\
\hline & & sod peat application & milled peat application \\
\hline Rucyahabi & 925 & 813,973 & 687,998 \\
\hline Akanyaru North-North part & 1321 & 501,291 & 68,753 \\
\hline Akanyaru North-Middle part & 1994 & $3,572,375$ & $2,026,147$ \\
\hline Akanyaru North-South part & 3208 & $15,740,346$ & $11,517,536$ \\
\hline Akanyaru south & 2108 & $7,797,785$ & $6,763,219$ \\
\hline Mukindo & 959 & $1,323,573$ & 698,581 \\
\hline Kaguhu & 195 & 69,712 & 64,942 \\
\hline Gishoma & 423 & 171,880 & 88,305 \\
\hline Gihitasi & 90 & 12,168 & 12,168 \\
\hline Mashya & 36 & 89,821 & 78,191 \\
\hline
\end{tabular}

Table 3. Characteristics of peat samples taken from Rwanda in 2015 (EDCL, 2014).

\begin{tabular}{|c|c|c|c|c|c|c|}
\hline Name of peat bog & $\begin{array}{l}\text { Top soil } \\
\text { depth }(\mathrm{m})\end{array}$ & $\begin{array}{l}\text { Peat layer } \\
\text { thickness (m) }\end{array}$ & $\begin{array}{l}\text { In-situ moisture } \\
\text { content ( } \% \mathrm{wt})\end{array}$ & $\begin{array}{l}\text { In-situ bulk } \\
\text { density }\left(\mathrm{kg} / \mathrm{m}^{3}\right)\end{array}$ & $\begin{array}{l}\text { Ave } \\
\text { con } \\
\text { dry }\end{array}$ & $\begin{array}{l}\text { ge ash } \\
\text { nt in-situ peat, } \\
\text { sis (\% wt) }\end{array}$ \\
\hline \multicolumn{6}{|c|}{ Average values of all samples taken } & $\begin{array}{l}\text { Top soil layer } \\
\text { not included }\end{array}$ \\
\hline Cyato & 2.5 & 2.4 & 74 & 1138 & 49 & 40 \\
\hline Murago & 0.8 & 5.7 & 83 & 1056 & 42 & 31 \\
\hline Rucyahabi & 1.8 & 3.7 & 80 & 1086 & 48 & 29 \\
\hline $\begin{array}{l}\text { Akanyaru North } \\
\text { (other), North }\end{array}$ & 2.4 & 2.1 & 68 & 1180 & 66 & 46 \\
\hline $\begin{array}{l}\text { Akanyaru North } \\
\text { (other), Middle }\end{array}$ & 0.8 & 4.6 & 78 & 1094 & 51 & 42 \\
\hline $\begin{array}{l}\text { Akanyaru North } \\
\text { (other, South) }\end{array}$ & 0.3 & 7.6 & 85 & 1037 & 31 & 28 \\
\hline Bishya & 1.2 & 2.4 & 70 & 1162 & 54 & 39 \\
\hline $\begin{array}{l}\text { Akanyaru south } \\
\text { (other) }\end{array}$ & 0.3 & 7.8 & 83 & 1061 & 30 & 20 \\
\hline Mukindo & 0.7 & 3.0 & 65 & 1207 & 64 & 43 \\
\hline Gishoma & 0.7 & 2.2 & 73 & 1139 & 53 & 31 \\
\hline Gihitasi & 0.6 & 2.0 & 73 & 1108 & 56 & 28 \\
\hline Mashya & 0.0 & 3.5 & 86 & 1016 & 20 & 9 \\
\hline Kaguhu & 0.9 & 0.9 & 53 & 1262 & 71 & 28 \\
\hline Bahimba & 0.7 & 1.3 & 55 & 1297 & 75 & 42 \\
\hline Bisika & 0.7 & 1.4 & 54 & 1278 & 77 & 73 \\
\hline Kageyo & 1.3 & 1.0 & 53 & 1287 & 80 & 45 \\
\hline Ndongozi & 0.1 & 2.9 & 76 & 1057 & 41 & 33 \\
\hline Nyirabirande & 0.9 & 2.4 & 67 & 1162 & 57 & 32 \\
\hline
\end{tabular}




\section{Conclusion}

The peat resources are playing a crucial role in the development of Rwanda but its quality is in doubt. The quality is not enough good for electrical power plant to run for many years and thus there is a need to develop a possible way to increase quality of harvested peat that is important to ensure long-term use for electrical generation. The analysis of earlier and new data depicts the most prospective bogs which are Murago, Rucyahabi, Akanyaru, Mukindo, Ndongozi and Nyirabirande. Besides evaluating the peat resources potential, the geochemical analysis can provide inputs such as peat forming vegetation, chemical characteristics and biogeochemical processes for developing environmentally safe production technology.

\section{Acknowledgements}

The authors thank the African Union Commission through Pan African University to provide grant to carry out this research. The anonymous reviewers are also acknowledged.

\section{Conflicts of Interest}

The authors declare no conflicts of interest regarding the publication of this paper.

\section{References}

Ahmed, M. T., Hasan, M. Y., Rifat, M. S. I., \& Rahman, M. (2019). Analysis of Fuel Properties for Peat: A Case Study. IOSR Journal of Applied Chemistry, 12, 26-43.

Andriesse, J. P. (1988). Nature and Management of Tropical Peat Soils. In FAO Soil Bulletin 59.

ASTM-E711 (1987). Standard Test Method for Gross Calorific Value of Refuse-Derived Fuel by the Bomb Calorimeter. Annual Book of ASTM Standards.

Bielowicz, B. (2013). Petrographic Composition of Polish Lignite and Its Possible Use in a Fluidized Bed Gasification Process. International Journal of Coal Geology, 116-117, 236-246. https://doi.org/10.1016/j.coal.2013.07.003

BIS (2003). Methods of Test for Coal and Coke (Second Revision of IS: 1350). Part I, Proximate Analysis (pp. 1-29). Bureau of Indian Standard.

Cohen, A. D., Spackman, S., \& Raymond, J. R. (1987). Interpreting the Characteristics of Coal Seams from Chemical, Physical and Petrographic Studies of Peat Deposits. Geological Society, London, Special Publications, 32, 107-125. https://doi.org/10.1144/GSL.SP.1987.032.01.08

de Clercq, F., Muchez, P., Dewaele, S. \& Boyce, A. (2008). The Tungsten Mineralisation at Nyakabingo and Gifurwe (Rwanda): Preliminary Results. Geologica Belgica, 11, 251-258.

Dehmer, J. (1993). Petrology and Organic Geochemistry of Peat Samples from a Raised Bog of Kalimantan (Borneo). Organic Geochemistry, 20, 340-362. https://doi.org/10.1016/0146-6380(93)90125-U

Del Rio, J. C., Gonzalez-Vila, F. J., \& Martin, F. (1992). Variation in the Content and Distribution of Biomarkers in Two Closely Situated Peat and Lignite Deposits. Organic Geochemistry, 18, 67-78. https://doi.org/10.1016/0146-6380(92)90144-M 
EDCL (2014). Detailed Study and Assessment of Peat Bogs in Rwanda and Their Potential Use as a Source of Fuel for Power Generation. Final Assessment Report.

Ekono (1992). Rwanda Peat Master Plan, Kigali.

Fernandez-Alonso, M., Cutten, H., Waelec, D., Tack, L., Tahon A., Baudet, D., \& Barritt, S. D. (2012). The Mesoproterozoic Karagwe-Ankole Belt (Formerly the NE Kibara Belt): The Result of Prolonged Extensional Intracratonic Basin Development Punctuated by Two Short-Lived Far-Field Compressional Events. Precambrian Research, 216-219, 63-86. https://doi.org/10.1016/j.precamres.2012.06.007

Hakizimana, J. de D. K., Yoon, S.-P., Kang, T.-J., Kim, H.-T., Jeon, Y.-S., \& Choi, Y.-C. (2016). Potential for Peat-to-Power Usage in Rwanda and Associated Implications. Energy Strategy Reviews, 13-14, 222-235. https://doi.org/10.1016/j.esr.2016.04.001

Hoş-Çebi, F., \& Korkmaz, S. (2015). Organic Geochemistry of Ağaçbaşı Yayla Peat Deposits, Köprübaşı/Trabzon, NE Turkey. International Journal of Coal Geology, 146, 155-165. https://doi.org/10.1016/j.coal.2015.05.007

Lindström, O. (1980). The Technology of Peat. Ambio, 9, 309-313.

Mugerwa, T. (2020). Organic Petrography and Geochemistry of Peat Deposits in Western Province, Rwanda. Unpublished Thesis, Nigeria: University of Ibadan \& Pan African University.

Mugerwa, T., Rwatangabo, D. E., Ehinola, O. A., Uwanyirigira, J., \& Muyizere, D. (2019). Rwanda Peat Deposits in Rwanda: An Alternative to Energy Sources. Energy Reports, 5, 1151-1155. https://doi.org/10.1016/j.egyr.2019.08.008

Namata, B. (2014). East African: Growing Demand Switches on Peat Company to Seek Capital Injection. Nairobi.

Pajunen, H. (1996). Mires as Late Quaternary Accumulation Basins in Rwanda and Burundin, Central Africa. Geological Survey of Finland, Bulletin 384.

Sarkki, J., Griffin, F., Scully, S., \& Flynn, T. (2012). CFB Technology in ESB Peat: Burning Power Stations. 21st International Conference on Fluidized Bed Combustion, Naples, Italy 2012, 20 p.

Schora, F. C., \& Punwani, D. V. (1980). An Energy Alternative. Vienna.

Sheng, C. D., \& Azevedo, J. L. T. (2005). Estimating the Higher Heating Value of Biomass Fuels from Basic Analysis Data. Biomass and Energy, 28, 499-507.

https://doi.org/10.1016/j.biombioe.2004.11.008

Shirazi, A. R., Börtin, O., Eklund, L., \& Lindqvist, O. (1995). The Impact of Mineral Matter in Coal on Its Combustion, and a New Approach to the Determination of the Calorific Value of Coal. Fuel, 74, 247-251. https://doi.org/10.1016/0016-2361(95)92661-O

Staub, J. R., Esterle, J. S., \& Raymond, A. L. (1991). Comparative Geomorphologic Analysis of Central Appalachian Coal Beds and Malaysian Peat Deposits. Bulletin de la Société Géologique de France, 162, 339-351.

Thomas, S. (2006). Atlas of Africa. New York: Springer Berlin Heidelberg.

Vitikka, A., \& Lahtinen, P. (2013). Rwanda Peat Master Plan Update. Final Report.

Zhu, Q. (2014). Coal Sampling and Analysis Standards. IEA Clean Coal Centre. 